\title{
The Effects of the Earnings Management and Corporate Governance on Expense Stickiness
}

\author{
Marzieh Hemati* and Dariush Javid
}

Islamic Azad University, Borujerd Branch, Iran

\begin{abstract}
Expense stickiness is an important issue in accounting and economics research. The recent studies demonstrate that the costs have asymmetrical behavior which means the rate of reduction in costs while reducing the sales is less than the rate of increasing the sales at the same rate. The asymmetrical behavior is called expense stickiness. The literature has shown that expense stickiness cannot be separated from managers' motivations. On the other hand, the mechanisms of corporate governance result in inhibition of managers' motivations. In this study, the influence of earnings management and corporate governance on expense stickiness has been carried out and the number of 112 firms was selected in the period of the years $2010-2016$ as a statistical sample. To analyze the data, the software EViews 7 is used. The regression model using panel data with fixed effects and random effects were investigated. The results of this study suggest that earnings management on expense stickiness is effective. The effects of corporate governance under two components ownership concentration and institutional ownership were investigated, and no significant relationship was observed.
\end{abstract}

Finally, we investigated the interaction effects of earnings management and corporate governance on expense stickiness. The empirical results show that no effects on cost stickiness.

Keywords: Earnings management; Corporate governance; Expense stickiness

\section{Introduction}

One of the important issues received the attention of managers and all firm stakeholders, particularly shareholders, is the situation of corporate profitability and the rate of firm's net income in particular. To reach a good income rate, paying attention to two factors, corporate earnings and particularly costs and fixed costs of firm has taken on special importance. One of the issues debated over costs frequently and is the topic of many accounting and financial studies are cost stickiness [1]. Traditionally, costs are assumed to behave symmetrically as cost drivers (e.g., sales) change. It has been recently found that costs are sticky. The term expense stickiness captures an asymmetric cost behavior response to the direction of a change in activities; that is, expenses increase more quickly with an increasing activity level than they decease with a declining activity level [2-4]. Because expense stickiness is an important issue in both accounting and economic researches, reflects the operating efficiency of corporate assets [5]. Cost stickiness is shown to be affected by capacity utilization, employee, asset intensity, sales trends, industry characteristics, corporate governance, earnings management, etc. $[4,6,7]$.

The results of previous research indicate that cost stickiness is heavily dependent on managements and managers motivations and is greatly affected by management decisions. By recognizing and predicting cost behaviors rigorously and how costs respond to income fluctuations, managers and researchers set out to develop regular and reliable programs and take wise decisions. Chen et al. [8] showed that costs got stickier as the managers' self-interests in empire-building or so were bigger. These results imply that the agency problem causes cost stickiness.

In this study, we investigated earnings management and corporate governance on expense stickiness. The literature consistently indicates that earnings management allows avoiding reporting losses or earnings decreases, meeting or beating consensus analysts' forecasts, reducing taxation, and decreasing the probability of debt covenant default.
The corporate governance includes the criteria that can reduce the managers' power to pursue their own interests by increasing the decentralization in the company controls and cause to improve the firm performances. Xue and Hong stated that good corporate governance has a negative effect on expense stickiness. Saffarzadeh explored the role of corporate governance in explanation of cost stickiness [9]. The results of the research suggest that there is a positive and significant relationship between corporate governance and level of cost stickiness. The reason for this positive relationship between two variables may be associated with managers' personal reasons for representative relationship. Although, Moharrampour and Nazari showed that corporate governance, has not significantly reduced cost stickiness [10].

Burgstahler and Dichev [11] and Degeorge et al. found that earnings management helps in the avoidance of reporting small losses and earnings decreases [12]. Roychowdhury and Cohen et al. further suggested that management reduces costs to avoid reporting losses or earnings decreases $[13,14]$. Koo found that firms reporting different levels of profits /losses have different incentive for earnings management and their incentives influence cost behaviors [7]. Firms reporting report small earnings and believed to have upward earnings management incentives show relatively weaker cost stickiness. On the other hand, costs reduction rates of firms reporting large profits were smaller when sales decline. It implies that managers with large incomes do not cut costs enough in order to smooth earning by reducing earning fluctuation with sales reduction. Finally, costs of firms with relatively

*Corresponding author: Hemati M, Islamic Azad University, Borujerd Branch, Iran, Tel: 02147352415; E-mail: mh.hemati.93@gmail.com

Received April 11, 2017; Accepted May 10, 2017; Published May 26, 2017

Citation: Hemati M, Javid D (2017) The Effects of the Earnings Management and Corporate Governance on Expense Stickiness. Int J Account Res 5: 161 doi:10.4172/2472-114X.1000161

Copyright: ( 2017 Hemati M, et al. This is an open-access article distributed under the terms of the Creative Commons Attribution License, which permits unrestricted use, distribution, and reproduction in any medium, provided the original author and source are credited. 
large losses are very sticky, implying that managers in large loss firms are taking big-baths instead of saving costs for future performance. Bolou et al. have studied the relationship between management perspective and costs stickiness in Tehran Stock Exchange [15]. According to their research when managers are optimistic about future sales, adhesion strength of costs is increased.

Given the importance of administrative, general and sales costs in the company's cost structure, in this study, the behavior of these costs rather some elements of corporate governance and Stickiness to these costs is investigated.

\section{The Research Hypotheses}

Therefore, we develop the following hypotheses:

H1: Earnings management significantly affects expense stickiness.

Compared with the studies on cost stickiness, there is no literature investigating whether a similar principle fits the explanation of expense stickiness. Although production costs (both variable and fixed) are unavoidable inputs for production so the occurrence of major parts of expenses, such as those for advertising and $\mathrm{R} \& \mathrm{D}$, and advertising is likely to be decided by managers. Thus, we expect earnings management incentives to affect expense stickiness. Therefore, to investigate whether the reduction of expense stickiness reflects efficient behavior, we divided expenses into Research and development (R\&D), advertising (ADV) and other general (GSGA) expenses. Therefore, H1 was divided into three parts:

\section{H1a: Earnings management significantly affects R\&D expenses.}

H1b: Earnings management significantly affects advertising expenses.

H1c: Earnings management significantly affects other general expenses.

H2: Corporate governance significantly affects expense stickiness.

Variables of corporate governance, whose effects on cost stickiness were addressed, include external corporate governance based on amount of institutional shareholders' ownership, and ownership concentration.

Therefore, $\mathrm{H} 2$ was divided into six parts:

H2a: Institutional ownership (INSOWN) significantly affects R\&D expenses.

H2b: Ownership concentration (OWNCON) significantly affects $\mathrm{R} \& \mathrm{D}$ expenses.

H2c: Institutional ownership significantly affects advertising expenses.

H2d: Ownership concentration significantly affects advertising expenses.

H2e: Institutional ownership significantly affects other general expenses.

H2f: Ownership concentration significantly affects other general expenses.

According to the first and second hypotheses, both upward earnings management and good corporate governance may help to reduce expense stickiness. Thus, it seems reasonable to consider their separate and interactive effects. Warfield et al. and Klein suggests that good corporate governance can restrict earnings management [16,17]. The literature usually takes earnings management as evidence of management opportunism.

H3: The interaction affects between earnings management and corporate governance can effect on expense stickiness.

\section{Research Design}

\section{Data}

This research is inductive-deductive based on the purpose of the research and is descriptive in term of method. The study is quantitative to collect data and analysis method. It uses objective approach to gather real data and analysis using statistical deals. Hence, due to reliable financial reporting of Tehran Stock Exchange companies, this report is used as the main source of information for research. This report includes financial statements and basic board of director's reports of financial companies, which is obtained through Exchange organization website, www.Codal.in for 2010-2016.

The initial sample consists of all the Companies listed in Tehran Stock Exchange during the years 2010 to 2016. Statistical sample was selected using the screening method and from among the companies that had the following conditions:

Companies that do not end their fiscal year end March; Companies that have been changes in financial in the review period; Completeness and availability of their data from 2010 to 2016; Companies that are related to intermediation groups, holding companies, banks and investment; Companies that do not have a trading interruption between 2010 and 2016.

According to the above conditions, 112 companies were selected; and the number of observations was 672 (companies-years).

\section{Variables}

According to the objective, there are three variables: dependent, independent and control variables.

\section{Dependent variables}

Expense stickiness (research model): This research aims to test the relationship between earnings management and corporate governance with expense stickiness. Consistent with the literature, we use the following logarithmic model (1) to measure expense stickiness.

$$
\begin{aligned}
& \log \left[\frac{S G A_{i-1}}{S G A_{i, t-1}}\right]=\beta_{0}+\beta_{1} \log \left[\frac{R E V_{i, t}}{R E V_{i, t-1}}\right]+\beta_{2} D U M * \log \left[\frac{R E V_{i, t}}{R E V_{i, t-1}}\right]+\beta_{2} D U M * C A P R_{i, 1} \\
& * \log \left[\frac{R E V_{i, t}}{R E V_{i, t-1}}\right]+\beta_{2} D U M * T O B Q_{i t} * \log \left[\frac{R E V_{i, t}}{R E V_{i, t-1}}\right]+\varepsilon_{i, t}
\end{aligned}
$$

Here, SGA=Natural log of total administration and operation expenses; REV=Natural log of revenue; DUM=A dummy variable with a value of 1 if the current year REV decreases $\left(\operatorname{REV}_{\mathrm{i}, \mathrm{t}} \mathrm{REV}_{\mathrm{i}, \mathrm{t}-1}<1\right)$, and 0 otherwise; $\mathrm{CAPR}=$ Capital intensity, measured as the net value of fixed assets scaled by operating revenue; $\mathrm{TOBQ}=$ Growth rate, measured as Tobin's $\mathrm{Q}$ (i indicates firm and $\mathrm{t}$ indicates year).

According to the definition of expense stickiness, a significant negative sign of $\beta 2$ in model (1) indicates the existence of expense stickiness.

R\&D, advertising (ADV), and other general expenses (GSGA): In order to estimate of R\&D, ADV and GSGA, information contained in the explanatory notes of the financial statements used. 
Citation: Hemati M, Javid D (2017) The Effects of the Earnings Management and Corporate Governance on Expense Stickiness. Int J Account Res 5: 161. doi:10.4172/2472-114X.1000161

Page 3 of 6

\section{Independent variables}

Earnings management: Accruals are one of the most popular measures of earnings management. This study uses the Jones model, the modified Jones model of Dechow et al. in order to estimate discretionary accruals (DA).

$$
\mathrm{DA}_{\mathrm{i}, \mathrm{t}}=\mathrm{TA}_{\mathrm{i}, \mathrm{t}}-\mathrm{NDA}_{\mathrm{i}, \mathrm{t}}
$$

Here, $\mathrm{TA}_{\mathrm{i}, \mathrm{t}}$ : Total accruals scaled by the beginning-of-year assets; $\mathrm{NDA}_{\mathrm{i}, \mathrm{t}}$ : Non-discretionary accruals of the company.

$$
\mathrm{TA}_{\mathrm{i}, \mathrm{t}}=\mathrm{E}_{\mathrm{i}, \mathrm{t}}-\mathrm{OCF}_{\mathrm{i}, \mathrm{t}}
$$

Here, $\mathrm{E}_{\mathrm{i}, \mathrm{t}}:$ Net profit before extraordinary items; $\mathrm{OCF}_{\mathrm{i}, \mathrm{t}}:$ Cash from the firm's operating activities.

After estimate TA, $\alpha_{1}, \alpha_{2}$ and $\alpha_{3}$ are measured by the following formula:

$$
\mathrm{TA}_{\mathrm{i}, \mathrm{t}}=\alpha_{1}\left(1 / \mathrm{A}_{\mathrm{i}, \mathrm{t}-\mathrm{1}}\right)+\alpha_{2}\left(\Delta \mathrm{REV}_{\mathrm{i}, \mathrm{t}} / \mathrm{A}_{\mathrm{i}, \mathrm{t}-\mathrm{l}}\right)+\alpha_{3}\left(\mathrm{PPE}_{\mathrm{i}, \mathrm{t}} / \mathrm{A}_{\mathrm{i}, \mathrm{t}-\mathrm{l}}\right)
$$

Here, $\mathrm{A}_{\mathrm{i}, \mathrm{t}-\mathrm{l}}$ : Total assets; $\Delta \mathrm{REV}_{\mathrm{i}, \mathrm{t}}$ : Change in sales normalized by beginning assets; $\mathrm{PPE}_{\mathrm{i}, \mathrm{t}}$ : Gross property plant and equipment scaled by beginning assets; $\alpha_{1}, \alpha_{2}$ and $\alpha_{3}$ : Estimated parameters of the company.

Finally, NDA was calculated using the following Formula:

$\mathrm{NDA}_{\mathrm{i}, \mathrm{t}}=\alpha_{1}\left(1 / \mathrm{A}_{\mathrm{i}, \mathrm{t}-\mathrm{t}}\right)+\alpha_{2}\left[\left(\Delta \mathrm{REV}_{\mathrm{i}, \mathrm{t}}-\Delta \mathrm{REC}_{\mathrm{i}, \mathrm{t}}\right) / \mathrm{A}_{\mathrm{i}, \mathrm{t}-\mathrm{l}}\right]+\alpha_{3}\left(\mathrm{PPE}_{\mathrm{i}, \mathrm{t}} / \mathrm{A}_{\mathrm{i}, \mathrm{t}-\mathrm{l}}\right)$

Here, $\Delta \mathrm{REC}_{\mathrm{i}, \mathrm{t}}$ : Change in accounts receivable.

Corporate governance: In order to estimate corporate governance, we used ownership concentration and institutional ownership. Ownership concentration was calculated as percent of institutional shareholders (CRH) according to Xue and Hong: CRH can be measured by taking the number of shares held by investment and commercial companies to the total equity of company at beginning of period. In order to estimate Institutional Ownership (INSOWN), the total percentage of all shareholders who hold at least $5 \%$ of the outstanding shares.

Control variables: The results of this study may vary due to some firm-specific circumstances, which need to be controlled for. In this study, we used the Return of assets (ROA) and firm size as control variables. Donker et al. have found that distressed firms are overall smaller in size; and Claessens et al. state that firm size is positively related to firm value as larger firm has a better disclosure and a more diversified portfolio.

ROA: According to Hamadi and Heinen ROA can be measured by taking the net income to total assets.

Size: Size $_{\mathrm{i}, \mathrm{t}}=$ Natural log of total assets $=>$ Size $_{\mathrm{i}, \mathrm{t}}=\ln$ (assets)

\section{Results}

The summary descriptive statistics of the main variables of 112 companies between 2010 and 2017 (672 companies-years) is presented in Table 1.

\section{Hypotheses tests}

\section{First hypotheses}

H1: Expense stickiness $=\alpha_{0}+\beta_{1} A D_{i, t}+\beta_{2} R A_{i, t}+\beta_{3}$ size $_{i, t}$

Results obtained using the software Eviews7 are shown in Table 2. As shown in it, significance level of $t$ Statistic in $A D$ and ROA is less than 0.05 therefore, $\mathrm{AD}$ and ROA significantly effect on expense stickiness. The result showed that AD had direct effect and ROA had inverse effect on expense stickiness but firm size had no significant effect on expense stickiness. In general, $\mathrm{H} 1$ at confidence level of $95 \%$ is accepted.

Given the obtained value of Durbin-Watson test in Table 2, the autocorrelation hypothesis is rejected. Results relating to the determination coefficient show that, almost $1.80 \%$ of the changes in dependent variable (expense stickiness) are described by independent and controlling model. According to the coefficient of constant, $\mathrm{AD}$ and ROA, The regression model of $\mathrm{H} 1$ is: Expense stickiness $=0.39+0.0$ $000000113 \mathrm{AD}_{\mathrm{i}, \mathrm{t}}-0.34 \mathrm{ROA}_{\mathrm{i}, \mathrm{t}}$

$$
\text { H1a: } R \& D=\alpha_{0}+\beta_{1} A D_{i, t}+\beta_{2} R O A_{i, t}+\beta_{3} \text { size }_{i, t^{\circ}}
$$

As shown in the Table 2, significance level of $\mathrm{t}$ Statistic in $\mathrm{AD}$ and Size is less than 0.05 . Therefore, AD and Size significantly effect on R\&D. However, ROA had no significant effect on R\&D. In general, $\mathrm{Hla}$ is accepted.

The value of Durbin-Watson test (1.31) in Table 2 showed that, the autocorrelation hypotheses is rejected. The results of the determination coefficient show that, almost $35 \%$ of the changes in dependent variable (expense stickiness) is described by independent and control variables. According to the coefficient of constant, $\mathrm{AD}$ and size, the regression model of H1a is: $\mathrm{R} \& \mathrm{D}=5.91+0.0000000264 \mathrm{AD}_{\mathrm{i}, \mathrm{t}}+0.44$ size $_{\mathrm{i}, \mathrm{t}^{\circ}}$

H1b: $A D V=\alpha_{0}+\beta_{1} \mathrm{AD}_{\mathrm{i}, \mathrm{t}}+\beta_{2} \mathrm{ROA}_{\mathrm{i}, \mathrm{t}}+\beta_{3}$ size $_{\mathrm{i}, \mathrm{t}^{*}}$

According to the significance level of $t$ Statistic in Table 3, AD and Size have significantly direct and inverse effect on ADV, respectively. However, ROA had no significant effect on ADV. Therefore, H1b is accepted.

The value of Durbin-Watson test (1.52) in Table 3 showed that, the autocorrelation hypotheses is rejected. The results of the determination coefficient show that, almost $27 \%$ of the changes in dependent variable

\begin{tabular}{|c|c|c|c|c|c|c|c|c|}
\hline & Variable & Mean & SD & Median & Skewness & Kurtosis & Min & Max \\
\hline \multirow[t]{4}{*}{ Dependent } & OG & 11.89 & 1.35 & 11.88 & 0.22 & 0.33 & 7.75 & 16.67 \\
\hline & ADV & 12.98 & 1.18 & 12.93 & 0.23 & 0.18 & 9.43 & 16.31 \\
\hline & R\&D & 11.91 & 1.34 & 11.91 & 0.14 & 0.23 & 7.66 & 15.44 \\
\hline & Sticky & 0.34 & 0.5 & 0.31 & 0.46 & 0.06 & -0.78 & 1.95 \\
\hline \multirow[t]{3}{*}{ Independent } & INSOWN & 0.65 & 0.23 & 0.71 & -0.81 & 0.11 & 0 & 0.98 \\
\hline & OWNCON & 0.78 & 0.19 & 0.84 & -1.9 & 4.21 & 0.04 & 0.99 \\
\hline & DA & 647115.61 & 3691819.2 & 153262.64 & 22.75 & 560.78 & 780.41 & 91992875 \\
\hline \multirow[t]{2}{*}{ Control } & ROA & 0.16 & 0.15 & 0.12 & 3.04 & 16.35 & 0 & 1.44 \\
\hline & Size & 13.57 & 1.48 & 13.47 & 0.75 & 1.49 & 9.61 & 18.63 \\
\hline
\end{tabular}
is described by independent and control variables. According to the coefficient of constant, $\mathrm{AD}$ and size, The regression model of $\mathrm{H} 1 \mathrm{~b}$ is: $\mathrm{ADV}=7.81+0.0000000318 \mathrm{ADi}, \mathrm{t}+0.37$ sizei,t.

Table 1: The results of descriptive statistics of variables ( $N=672$ companies-years). 
Citation: Hemati M, Javid D (2017) The Effects of the Earnings Management and Corporate Governance on Expense Stickiness. Int J Account Res 5: 161. doi:10.4172/2472-114X.1000161

Page 4 of 6

\begin{tabular}{|c|c|c|c|c|c|}
\hline \multirow{7}{*}{ H1 } & Variable & Coefficient & SE & t Statistic & Significant \\
\hline & Constant & 0.39 & 0.18 & 2.17 & 0.03 \\
\hline & $A D$ & $1.13 \mathrm{E}$ & $5.17 \mathrm{E}$ & 2.18 & 0.03 \\
\hline & ROA & -0.34 & 0.12 & -2.70 & 0.007 \\
\hline & Size & $1.60 \mathrm{E}$ & 0.01 & 0.001 & 0.99 \\
\hline & \multicolumn{2}{|c|}{ Coefficient of determination } & 0.018 & F Statistic & 4.20 \\
\hline & \multicolumn{2}{|c|}{ Modified Coefficient of determination } & 0.014 & Durbin-Watson & 1.58 \\
\hline \multirow{6}{*}{ H1a } & Constant & 5.91 & 0.93 & 15.00 & 0.00 \\
\hline & $A D$ & $2.64 \mathrm{E}$ & $1.14 \mathrm{E}$ & 2.32 & 0.02 \\
\hline & ROA & -0.02 & 0.27 & -0.09 & 0.92 \\
\hline & Size & 0.44 & 0.03 & 15.26 & 0.00 \\
\hline & \multicolumn{2}{|c|}{ Coefficient of determination } & 0.35 & F Statistic & 44.86 \\
\hline & \multicolumn{2}{|c|}{ Modified Coefficient of determination } & 0.34 & Durbin-Watson & 1.31 \\
\hline
\end{tabular}

Table 2: The results of testing $\mathrm{H} 1$ and $\mathrm{H} 1 \mathrm{a}$ on the cost stickiness.

\begin{tabular}{|c|c|c|c|c|c|}
\hline \multirow[t]{7}{*}{ H1b } & Variable & Coefficient & SE & t Statistic & Significant \\
\hline & Constant & 7.81 & 0.37 & 21.31 & 0.00 \\
\hline & $A D$ & $3.18 \mathrm{E}$ & $1.17 \mathrm{E}$ & 2.72 & 0.00 \\
\hline & ROA & 0.38 & 0.26 & 1.47 & 0.14 \\
\hline & Size & 0.37 & 0.03 & 13.90 & 0.00 \\
\hline & \multicolumn{2}{|c|}{ Coefficient of determination } & 0.27 & F Statistic & 31.23 \\
\hline & \multicolumn{2}{|c|}{ Modified Coefficient of determination } & 0.26 & Durbin-Watson & 1.52 \\
\hline \multirow[t]{6}{*}{ H1c } & Constant & 4.28 & 0.37 & 11.41 & 0.00 \\
\hline & $A D$ & $2.21 \mathrm{E}$ & $1.13 \mathrm{E}$ & 1.99 & 0.04 \\
\hline & ROA & -1.08 & 0.27 & -3.94 & 0.00 \\
\hline & Size & 0.57 & 0.03 & 20.68 & 0.00 \\
\hline & \multicolumn{2}{|c|}{ Coefficient of determination } & 0.40 & F Statistic & 149.33 \\
\hline & \multicolumn{2}{|c|}{ Modified Coefficient of determination } & 0.398 & Durbin-Watson & 1.55 \\
\hline
\end{tabular}

Table 3: The results of testing $\mathrm{H} 1 \mathrm{~b}$ and $\mathrm{H} 1 \mathrm{c}$ on the cost stickiness.

\begin{tabular}{|c|c|c|c|c|c|}
\hline \multirow[t]{8}{*}{$\mathrm{H} 2$} & Variable & Coefficient & SE & t Statistic & Significant \\
\hline & Constant & 0.18 & 0.21 & 0.88 & 0.38 \\
\hline & OWNCON & 0.47 & 0.39 & 1.21 & 0.22 \\
\hline & INSOWN & -0.18 & 0.31 & -0.58 & 0.56 \\
\hline & ROA & -0.35 & 0.12 & -2.84 & 0.00 \\
\hline & Size & -0.003 & 0.01 & -0.21 & 0.83 \\
\hline & \multicolumn{2}{|c|}{ Coefficient of determination } & 0.02 & F Statistic & 3.73 \\
\hline & \multicolumn{2}{|c|}{ Modified Coefficient of determination } & 0.016 & Durbin-Watson & 1.58 \\
\hline
\end{tabular}

Table 4: The results of testing $\mathrm{H} 2$ on the cost stickiness.

H1c: GSGA $=\alpha_{0}+\beta_{1}$ Earnings management ${ }_{i, t}+\beta_{2} R A_{i, t}+\beta_{3}$ size $_{i, t}$.

According to the significance level of $t$ Statistic in Table $3 \mathrm{AD}$, ROA and Size significantly effect on GSGA. AD and Size have direct effect but ROA has inverse effect on GSGA. According to that, H1c at confidence level of $99 \%$ is accepted. The amount of Durbin-Watson is 1.55 and this, shows the lack of self-correlation. The results of the determination coefficient show that, almost $40 \%$ of the changes in dependent variable is described by independent and control variables. According to the coefficient of constant, $\mathrm{AD}$ and size, The regression model of $\mathrm{H1c}$ is: $\mathrm{GSGA}=4.28+0.0000000221 \mathrm{AD}_{\mathrm{i}, \mathrm{t}}-1.08 \mathrm{ROA}_{\mathrm{i}, \mathrm{t}}+0.57$ size $_{\mathrm{i}, \mathrm{t}}$. $^{\circ}$

The second hypotheses: According to the significance level of $t$ Statistic in Table 4, corporate governance has no significant effect on Expense stickiness. Therefore, $\mathrm{H} 2$ is rejected.

From Tables 5 and 6 , the relationship between two variables in all hypotheses is not statistically significant. In the other words, H2a, b, c, $\mathrm{d}$, e and $\mathrm{f}$ are rejected.

\section{Third hypotheses}

H3: Expense stickiness $=\alpha_{0}+\beta_{1} \mathrm{AD}_{\mathrm{i}, \mathrm{t}}+\beta_{2}$ corporate governance $\mathrm{i}_{\mathrm{i}, \mathrm{t}}+\beta_{3} \mathrm{R}$ $\mathrm{OA}_{\mathrm{i}, \mathrm{t}}+\beta_{4}$ size $_{\mathrm{i}, \mathrm{t}}$.

According to the significance level of $\mathrm{t}$ Statistic in Table 7, AD significantly have effect on Expense stickiness. However, CRH and Owning have no significant effect on Expense stickiness. Therefore, the interaction affects between earnings management and corporate have no effect on expense stickiness. Therefore, $\mathrm{H} 3$ is rejected.

\section{Summary and Conclusion}

This study determines the effects of earnings management and corporate governance on the expense stickiness using representative sample of 112 companies listed in Tehran stock exchange. Given the importance of $\mathrm{ADV}, \mathrm{R} \& \mathrm{D}$ and GSGA expenses, in this study, the behavior of these costs is investigated.

In the first hypotheses, it was acknowledged that earnings management has significant effect on expense stickiness, ADV, R\&D and GSGA expenses. In other words, with increase in earnings 
Citation: Hemati M, Javid D (2017) The Effects of the Earnings Management and Corporate Governance on Expense Stickiness. Int J Account Res 5: 161. doi:10.4172/2472-114X.1000161

Page 5 of 6

\begin{tabular}{|c|c|c|c|c|c|c|}
\hline & Variable & Coefficient & SE & t Statistic & Significant & Final Result \\
\hline \multirow[t]{6}{*}{$\mathrm{H} 2 \mathrm{a}$} & Constant & 5.80 & 0.42 & 13.92 & 0.00 & \multirow{4}{*}{$\mathrm{H} 2 \mathrm{a}$ is rejected } \\
\hline & OWNCON & 0.11 & 0.22 & 0.52 & 0.60 & \\
\hline & ROA & -0.05 & 0.28 & -0.19 & 0.85 & \\
\hline & Size & 0.44 & 0.03 & 15.24 & 0.00 & \\
\hline & \multicolumn{3}{|c|}{ Coefficient of determination } & 0.35 & F Statistic & 43.89 \\
\hline & \multicolumn{3}{|c|}{ Modified Coefficient of determination } & 0.338 & Durbin-Watson & 1.60 \\
\hline \multirow[t]{6}{*}{$\mathrm{H} 2 \mathrm{~b}$} & Constant & 5.85 & 0.40 & 14.48 & 0.00 & \multirow[t]{4}{*}{$\mathrm{H} 2 \mathrm{~b}$ is rejected } \\
\hline & INSOWN & 0.06 & 0.18 & 0.36 & 0.71 & \\
\hline & ROA & -0.05 & 0.28 & -0.19 & 0.85 & \\
\hline & Size & 0.44 & 0.03 & 15.27 & $0 / 00$ & \\
\hline & \multicolumn{3}{|c|}{ Coefficient of determination } & 0.35 & F Statistic & 43.86 \\
\hline & \multicolumn{3}{|c|}{ Modified Coefficient of determination } & 0.34 & Durbin-Watson & 1.59 \\
\hline \multirow[t]{6}{*}{$\mathrm{H} 2 \mathrm{c}$} & Constant & 7.71 & 0.38 & 19.38 & 0.00 & \multirow[t]{4}{*}{$\mathrm{H} 2 \mathrm{c}$ is rejected } \\
\hline & OWNCON & 0.09 & 0.21 & 0.35 & 0.62 & \\
\hline & ROA & 0.35 & 0.26 & 1.33 & 0.18 & \\
\hline & Size & 0.38 & 0.3 & 13.92 & 0.00 & \\
\hline & \multicolumn{3}{|c|}{ Coefficient of determination } & 0.26 & F Statistic & 29.74 \\
\hline & \multicolumn{3}{|c|}{ Modified Coefficient of determination } & 0.255 & Durbin-Watson & 1.57 \\
\hline
\end{tabular}

Table 5: The results of testing $\mathrm{H} 2 \mathrm{a}, \mathrm{H} 2 \mathrm{~b}$ and $\mathrm{H} 2 \mathrm{c}$ on the cost stickiness.

\begin{tabular}{|c|c|c|c|c|c|c|}
\hline & Variable & Coefficient & SE & t Statistic & Significant & Final Result \\
\hline \multirow[t]{6}{*}{ H2d } & Constant & 7.77 & 0.37 & 20.69 & 0.00 & \multirow[t]{4}{*}{$\mathrm{H} 2 \mathrm{~d}$ is rejected. } \\
\hline & INSOWN & -0.01 & 0.17 & -0.05 & 0.96 & \\
\hline & ROA & 0.35 & 0.26 & 1.33 & 0.18 & \\
\hline & Size & 0.38 & 0.03 & 13.98 & 0.00 & \\
\hline & \multicolumn{3}{|c|}{ Coefficient of determination } & 0.26 & F Statistic & 29.71 \\
\hline & \multicolumn{3}{|c|}{ Modified Coefficient of determination } & 0.25 & Durbin-Watson & 1.58 \\
\hline \multirow[t]{6}{*}{$\mathrm{H} 2 \mathrm{e}$} & Constant & 4.16 & 0.39 & 10.52 & 0.00 & \multirow[t]{4}{*}{$\mathrm{H} 2 \mathrm{e}$ is rejected } \\
\hline & OWNCON & 0.15 & 0.22 & 0.67 & 0.50 & \\
\hline & ROA & -1.10 & 0.27 & -4.02 & 0.00 & \\
\hline & Size & 0.57 & 0.03 & 20.59 & 0.00 & \\
\hline & \multicolumn{3}{|c|}{ Coefficient of determination } & 0.40 & F Statistic & 147.36 \\
\hline & \multicolumn{3}{|c|}{ Modified Coefficient of determination } & 0.39 & Durbin-Watson & 1.56 \\
\hline \multirow[t]{6}{*}{$\mathrm{H} 2 \mathrm{f}$} & Constant & 4.21 & 0.38 & 11.00 & 0.00 & \multirow[t]{4}{*}{$\mathrm{H} 2 \mathrm{f}$ is rejected } \\
\hline & INSOWN & 0.08 & 0.17 & 0.48 & 0.62 & \\
\hline & ROA & -1.10 & 0.27 & -4.02 & 0.00 & \\
\hline & Size & 0.57 & 0.03 & 20.62 & 0.00 & \\
\hline & \multicolumn{3}{|c|}{ Coefficient of determination } & 0.40 & F Statistic & 147.24 \\
\hline & \multicolumn{3}{|c|}{ Modified Coefficient of determination } & 0.39 & Durbin-Watson & 1.56 \\
\hline
\end{tabular}

Table 6: The results of testing $\mathrm{H} 2 \mathrm{~d}, \mathrm{H} 2 \mathrm{e}$ and $\mathrm{H} 2 \mathrm{f}$ on the cost stickiness.

\begin{tabular}{|c|c|c|c|c|c|}
\hline \multirow[t]{9}{*}{ H3 } & Variable & Coefficient & SE & t Statistic & Significant \\
\hline & Constant & 0.19 & 0.21 & 0.93 & 0.35 \\
\hline & DA & $1.14 \mathrm{E}$ & $5.14 \mathrm{E}$ & 2.22 & 0.03 \\
\hline & OWNCON & 0.50 & 0.39 & 1.29 & 0.20 \\
\hline & INSOWN & -0.20 & 0.31 & -0.65 & 0.51 \\
\hline & ROA & -0.34 & 0.12 & -2.74 & 0.00 \\
\hline & Size & -0.005 & 0.01 & -0.38 & 0.71 \\
\hline & \multicolumn{2}{|c|}{ Coefficient of determination } & 0.03 & F Statistic & 3.98 \\
\hline & \multicolumn{2}{|c|}{ Modified Coefficient of determination } & 0.023 & Durbin-Watson & 1.58 \\
\hline
\end{tabular}

Table 7: The results of testing $\mathrm{H} 3$ on the cost stickiness.

management, expense stickiness, ADV, R\&D and GSGA expenses is also increased.

The results obtained from the second hypotheses consisting of two variables (ownership concentration and institutional ownership) of corporate governance suggest that the variables have no significant effect on reduction of cost stickiness.

Finally, we investigated the interaction effects of earnings management and corporate governance on expense stickiness. The empirical results show that no effects on cost stickiness.

\section{References}

1. Anderson M, Banker R, Janakiraman S (2003) Are Selling, General, and Administrative Costs 'Sticky'?. Journal of Accounting Research 41: 47-63.

2. Liu QGH, Shen H (2010) The Development of Regional Factor Market, State Holding and Cost Stickiness. China Journal of Accounting Research 4: 431-446. 
Citation: Hemati M, Javid D (2017) The Effects of the Earnings Management and Corporate Governance on Expense Stickiness. Int J Account Res 5: 161. doi:10.4172/2472-114X.1000161

3. Chen C, Lu H, Sougiannis T (2008) Managerial Empire Building, Corporate Governance, and the Asymmetrical Behavior of Selling, General, and Administrative Costs. Working paper.

4. Cooper R, Kaplan RS (1998) Cost \& Effect - Using Integrated Cost Systems to Drive Profitability and Performance. Harvard Business Press, Boston.

5. Ola MR, Ghavidel Z (2014) Considering the Effect of Costs Stickiness on Corporate Governance Quality. International Journal of Scientific Management and Development 2: 30-37.

6. Noreen E, Soderstrom N (1997) The Accuracy of Proportional Cost Models: Evidence from Hospital Service Departments. Review of Accounting Studies Journal 2: 89-114

7. Koo J (2011) The Effect of Earnings Management Incentives on the Asymmetric Cost Behaviour: Focusing on loss avoiding, income smoothing and big-bath. Korean Accounting Review 36: 135-177.

8. Chen C, Lu H, Sougiannis T (2012) The Agency Problem, Corporate Governance, and the Asymmetrical Behavior of Selling, General and Administrative Costs. Contemporary Accounting Research 29: 252-282.

9. Saffarzadeh MH (2014) The Role of Corporate Governance in Explanation of Cost Stickiness. Journal of Financial Accounting 23: 1-21.
10. Moharrampour M, Nazari H (2016) Investigate the Role of Corporate Governance on Expense Stickiness in Firms Accepted in Tehran Stock Exchange. Iranian Journal of Business and Economics 3: 288-291.

11. Burgstahler D, Dichev I (1997) Earnings Management to Avoid Losses and Earnings Decreases. Journal of Accounting and Economics 24: 99-126.

12. Degeorge F, Patel J, Zeckhauser R (1999) Earnings Management to Exceed Thresholds. Journal of Business 72: 1-33.

13. Roychowdhury S (2006) Earning management through real activities manipulation. Journal of Accounting and Economics 42: 335-370.

14. Cohen D, Dey A, Lys T (2008) Real and accrual-based earnings management in the pre and post sarbanes oxley periods. Accounting Review 82: 757-787.

15. Bolou G, Babajani J, Meymand M (2012) The Relationship Between Management Perspective and Costs Stickiness in Tehran Stock Exchange. Journal of Financial Accounting Research 1: 47-66.

16. Warfield TD, Wild JJ, Wild KL (1995) Managerial ownership, accounting choices, and informativeness of earnings. Journal of Accounting and Economics 20: $61-91$

17. Klein A (2002) Audit Committee, Board of Director Characteristics, and Earnings Management. Journal of Accounting and Economics 33: 375-400. 